\title{
Does being taught by native English-speaking teachers promote improvement in speaking skill more?
}

\author{
Gülten Koşar*
}

APA Citation:

Hatay Mustafa Kemal University, Hatay, 31060, Turkey

Koşar, G. (2019). Does being taught by native English-speaking teachers promote improvement in speaking skill more? Journal of Language and Linguistic Studies, 15(3), 989-999.

Submission Date: $24 / 06 / 2019$

Acceptance Date:22/07/2019

\begin{abstract}
It has been conceived that being taught by native English-speaking teachers (NESTs) leads to more improvement in speaking proficiency given the fact that English is their mother tongue. This paper aims to examine whether or not being taught by NESTs ends up with more achievement in adult EFL learners' speaking skills. Experimental research design was used with an eye to scrutinizing if there was a statistically significant difference between the speaking scores of the participants in the experimental group and the ones got by the participants in the control group. The experimental group had proportionately more lessons conducted by NESTs as opposed to the control group taught predominantly by non-native English-speaking teachers (NNESTs). In eight weeks, marking the duration of the study, the participants submitted three speaking portfolios, took one speaking quiz and one end-ofcourse test (ECT). Participants' scores on the quiz, the ECT and the speaking portfolios were analyzed via conducting independent samples t-test. The findings obtained from the analyses show that no statistically significant difference exists between the speaking scores of the experimental and control group on the ECT, scores on the speaking quiz, the first and second speaking portfolios while a statistically significant difference is observed between the participants' scores on the third speaking portfolio. The results might arouse suspicion of the popular conception of learning to speak English better as a consequence of being taught by NESTs.
\end{abstract}

C 2019 JLLS and the Authors - Published by JLLS.

Keywords: Adult EFL learners; NESTs; NNESTs; improvement in speaking skill; speaking skill

\section{Introduction}

Enhancing proficiency levels in language skills is what is sought for in EFL/ESL learning, and what is resorted to on the way towards accomplishing this objective may differ from one learner to another. This variation resides in a wide range of factors subsuming the time allocated to learning English, beliefs about English language learning, previous English language learning experiences, availability of chances for immediate application of the newly learned patterns, use of technology, awareness and application of language learning strategies, so on so forth. The nationality of the teacher is also assumed to influence students' achievement levels specifically in speaking skill; to put in other words, having a NEST is construed to be one of the determinants of being capable of communicating in English, which

\footnotetext{
* Corresponding author. Tel.: +905062485948

E-mail address: gencoglugulten@gmail.com
} 
might be contemplated to be one of the misconceptions concerning equating the success in speaking English to being taught by a NEST.

\subsection{Means to facilitate students' speaking skill}

Literature entails a plethora of research investigating diverse means to be utilized to improve EFL/ESL learners' speaking skills (Bygate, 2010; Cepik \& Yastıbaş, 2013; Dowling, 1957; Ebadi \& Asakereh, 2017; Gonzales \& Castaneda, 2018; Gupta \& Stern, 2015; Hassani, Nahvi \& Ahmadi, 2013; Hayward, 2017; Hudges, 2011; Mahfouz \& Ihmeideh, 2009; Hunter, Westwick \& Haleta, 2014; Nation \& Newton, 2008; Richards, 2008; Uztosun, Skinner \& Cadorath, 2014; Sun, Lin, You, Shen, Qi \& Lou, 2017). One of those studies was carried out by Forbes and Fisher (2018) with the purpose of examining the impact of metacognitive learning strategies on students' speaking skills. The findings of that study revealed that enhancing secondary level students' awareness and use of metacognitive learning strategies led to the heightened levels of confidence and improved proficiency in speaking skill. Confidence, creativity of topics and speaking competence were presented in the findings of the research undertaken by Boonkit (2010) as factors impinging on speaking skills of non-native speakers of English. Another study was conducted by Uchihara and Saito (2016) to scrutinize the correlation between productive vocabulary knowledge and second language oral ability, the results of which indicated that more proficient L2 learners in terms of having higher productive vocabulary scores were more fluent as they could speak with a faster tempo, less pausing and repetitions. Gan (2013) produced a paper with an eye to delving into the reasons underlying the difficulties pertinent to speaking English experienced by tertiary-level EFL learners. The results of the study indicated that linguistic competence was among the reasons of the hurdles encountered by the participants while speaking. Other difficulties presented in the findings of the study embrace lack of opportunities to speak English and hardship of developing academic speaking skill. The research done by Zou (2013) searched the influence of teacher support given on CALL tasks to develop tertiary-level students' speaking skill. The study reports that teacher support helped the participants use computers more effectively as practicing speaking.

\subsection{Existing research on the advantages and disadvantages of NESTs and NNESTs}

The related literature contains extensive research undertaken to uncover students' perceptions as to the advantages and disadvantages of NESTs and NNESTs, and to explore NESTs' and NNESTs' views on the differences between their own and the other party's teaching practices. One of the studies examining the reasons for the distinctions in the teaching practices of NESTs and NNESTs is done by Medgyes (1992) who links the differences in teaching practices to the distinctions in teachers' language proficiency. Reves \& Medgyes (1994) also conducted international research via administering a survey with 216 NESTs and NNESTs from 10 countries to investigate three hypotheses one of which was NNESTs and NESTs differed as to their teaching practices mainly resulting from their language proficiency. The findings of the study showed for $68 \%$ of the subjects, there existed differences between the teaching practices of NESTs and NNESTs, and $84 \%$ of the NNESTs stated that they experienced hardships in vocabulary and fluency prevalently, followed by the problems with speaking, pronunciation and listening comprehension. Similarly, the results reported in the study carried out by Samimy and Brutt-Griffler (1999) with the participation of 17 NNESTs continuing their MA and PhD studies in TESOL showed that an overwhelming majority of the subjects acknowledged the differences between NESTs and NNESTs. Nonetheless, the researchers attributed the distinctions between NESTs and NNESTs to the socio-cultural factors displaying differentiation between Western and Asian societies.

Another research aiming to examine how NNESTs' perceptions with regard to their levels in language skills and how that affected their teaching was conducted by Llurda \& Huguet (2003). The findings attained from the analysis of the data gathered from 101 non-native primary and secondary 
school teachers showed that secondary school teachers viewed their language skills sufficient to teach particularly grammar and reading. The findings in relation to primary school teachers reported that they did not relate the difficulties encountered in teaching to their language proficiency. In this study, half of the primary school teachers stated that they would hire more NESTs for a language school whilst the two-thirds of the secondary school teachers stated that they would hire NESTs and NNESTs equally, which shows that primary school teachers perceived NESTs better at teaching English as opposed to secondary school teachers. Gonzales (2016) examined pre-service EFL teachers' perceptions of themselves, the findings of which reported that participants were concerned about their future professional lives as a consequence of not being able to develop their language skills to become a nativelike speaker. The findings, however, also indicated that they felt more confident about working as a teacher considering the positive impact of coming from the same culture as that of the students, and their prospective function of building a bridge between Spanish and English culture.

In addition to how NNESTs perceive themselves in comparison to NESTs, students' perceptions of NESTs and NNESTs are explored in a large number of research. One of them was done by Benke \& Medgyes (2006) with the participation of 422 Hungarian learners of English. The findings showed that the majority of the participants viewed NNESTs as teachers "assigning lots of homework" and "getting prepared conscientiously for lessons", and preparing learners well for the exams whereas NESTs were perceived as teachers "focusing primarily on speaking skills", "happy to improvise", and "providing extensive information about culture". In that study, one of the miscellaneous statements, "in an ideal situation both native and non-native teacher should teach you" was chosen by the majority of the participants. The results also yielded that NNESTs were valued in terms of teaching grammar and providing Hungarian equivalents of English words, but they were criticized on the grounds that their pronunciation was bad and they used outdated language. NESTs were perceived to be good models of speaking English and the ones to teach conversation classes.

In the research conducted by Lasagabaster and Sierra (2006), the respondents opted for NESTs in the areas of teaching pronunciation, speaking, vocabulary, culture and listening while NNESTs were perceived to be better at teaching grammar and strategy training. Diaz (2015) did a study with a view to examining 78 French university students' perceptions of NESTs and NNESTs, the results of which reported that NNESTs were preferred over NESTs. The participants opted for both of them in teaching grammar, vocabulary, culture and strategies while they went for NESTs in teaching oral production. Guerra (2009) undertook a study to learn about 274 Portuguese university students' perceptions concerning whether they wanted to learn English from NESTs or NNESTs. The findings obtained from the open-ended questionnaire indicated that they preferred NESTs to improve their pronunciation skills and to practice English, and they valued NNESTs more considering the chance to receive explanations in Portuguese, and the ability of NNESTs in understanding the hurdles they experienced in English language learning. A similar study was conducted by Guerra (2017) with 32 Portuguese college-level students, the findings of which showed that NESTs were preferred over NNESTs as their language proficiency was higher; however, NNESTs were viewed to be advantageous over NESTs, taking into consideration NNESTs' heightened awareness of students' needs and commitment to teaching.

Lewis, Sonsaat, Link and Barriusso (2016) explored the impact of teacher's first language on ratings of accentedness and comprehensibility, and the findings show that the ratings of native listeners regarding comprehensibility were similar for both NESTs and NNESTs even though most of the participants went for NESTs. The research conducted by Lewis, Sonsaat and Link (2017) revealed that the participating ESL and EFL learners preferred NESTs over NNESTs in pronunciation teaching while the results showed that they were inapt in differentiating native speech from non-native one. Another finding obtained in the study indicated that both EFL and ESL learners favored teachers possessing pedagogical knowledge and teaching experience. 


\subsection{The impact of NESTs on students' speaking skills}

Al-Nawrasy (2013) undertook a study to examine the impact of NESTs on high-school students' achievement level in speaking. The results yielded by administering a speaking test revealed that no statistically significant difference existed between students' speaking test scores stemming from being taught by NESTs. Similar to the results of the study done by Al-Nawrasy (2013), the research conducted by Adıgüzel and Özdoğru (2017) with the purpose of investigating the impact of NESTs and NNESTs on students' academic achievements and speaking skills revealed that there was no statistically significant difference between the post-speaking test scores of the participants being taught by NESTs and NNESTs.

In view of the limited number of research studies examining the effect of being taught by NESTs on students' achievement level in speaking, the researcher decided to carry out this investigation. Another point which led the researcher to conduct this study is the inexistence of a study scrutinizing the influence of NESTs and NNESTs on students' speaking skills within the process of learning English via analyzing speaking scores gathered from various data collection tools rather than merely using the results from a pre- and post-test as it has been done in the related research heretofore. The research question to which an answer is sought in this study via testing participants' progress in speaking skill within language learning process is if or not being taught by NESTs and NNESTs results in a statistically significant difference in adult EFL learners' speaking achievement levels.

\section{Method}

\subsection{Research Design}

This true experimental research was carried out to explore whether there was a statistically significant difference between the speaking achievement levels of the participants who were taught by NESTs and NNESTs because as stated by Feuer, Towne and Shavelson (2002), "when well-specified causal hypotheses can be formulated and randomization to treatment and control conditions is ethical and feasible, a randomized experiment is the best method for estimating effects" (p. 8). To investigate the difference between the speaking achievement levels of the participants, if any, rooted in the nativeness or non-nativeness of the teacher, the participants were randomly assigned either to experimental group being mostly instructed by NESTS for eight weeks or the control group in which instructors were mainly NNESTs. The scores of the experimental and control group on the speaking portfolios, the speaking quiz, and the ECT administered during the study were compared to each other to research the existence of difference originating from being taught by NESTs and NNESTs.

\subsection{Participants}

Participants of this study included 36 university level students attending the English preparatory program of a state university. While 19 participants took part in the study in the experimental group, the control group was comprised of 17 participants. The average age of the participants was 18 . The participants were at upper-intermediate level when this research was conducted.

\subsection{Context of the study}

The preparatory school of the university where this study was carried out hires native speakers who hold a BA or a post-graduate degree on education or specifically on English language teaching to support students' learning. NESTs teaching the experimental group in this study are from the USA. 17 of a total 
of 25 lessons were offered by NESTs in the experimental group per week whereas only 6 lessons were taught by NESTs in the control group, which means that 8 lessons in the experimental group and 19 lessons in the control group were offered by NNESTs.

The preparatory school takes on formative assessment on the purpose of assessing students' progress in English language learning. Pertaining to assessment of students' speaking skill progression, students are to take one ECT involving a spoken exam, one speaking quiz, and to submit 3 speaking portfolios in each module lasting eight weeks.

\subsection{Data Collection Tools}

\subsubsection{The ECT}

The participants took the ECT at the end of week eight marking the completion of the module and the study. The ECT is comprised of two parts as written and spoken exam, and the questions in the spoken exam were prepared by the testing unit of the school considering the speaking tasks covered in the coursebook. A topic and prompts pertinent to it were given to two students and they were expected to talk about it for three minutes following the end of 45 seconds given for preparation. Participants' performances on the speaking exam were video recorded to maintain objectivity and to refer to the recording in case the participants objected to their scores. Two assessors assessed the participants' performance on the speaking exam, and while one of the assessors used a holistic rubric, the other used an analytic one. The average of the scores awarded by the two assessors was taken. To ensure the interrater reliability, intraclass coefficient correlation (ICC) value was calculated by using SPSS. The finding as to the ICC for average measures is, 727 , indicating an acceptable level of reliability between two raters in the ECT speaking exam taken by the control group. The ICC value for average measures belonging to the ECT speaking exam scores of the experimental group is ,764, signaling an acceptable inter-rater reliability.

\subsubsection{The speaking quiz}

Another tool used to find out an answer to the research question is the speaking quiz taken by the participants in the fourth week of the module. The participants were assessed in pairs according to their contributions to the discussion on the topic prepared by the testing unit in the light of the speaking tasks given in the coursebook. Prior to commencing to talk about the topic for two minutes, 30 seconds were allocated to the students to organize their thoughts on it. Two assessors assessed participants' performance on the quiz, and the first assessor used an analytic rubric whereas the second utilized a holistic rubric. At the end of the quiz, the average of the scores given by the two assessors was calculated, and the obtained score determined the real score of each participant. ICC was calculated to explore the degree of the agreement of two raters' estimates. The ICC value for average measures of the speaking quiz scores of the control group is, 973 , indicating a perfect inter-rater reliability, and the one pertaining to the speaking quiz scores of the experimental group is ,795, showing almost a high level of inter-rater reliability between the raters.

\subsubsection{The speaking portfolios}

The participants had to submit three speaking portfolios in eight weeks, one at the end of the second week, one at the end of the fourth week and the last one at the end of the seventh week. The topics in the speaking portfolios were prepared by the curriculum unit of the school by taking into account the speaking tasks available in the coursebook. The speaking portfolios were prepared individually by the participants and marked by only one assessor having to use an analytic rubric. The participants were informed about the content of each portfolio and the due dates one week before the submission date. Speaking portfolio scores affected participants' overall module mark. 


\subsection{Data analysis}

Independent samples t-test was conducted to analyze the data gathered by administering the ECT, the speaking quiz and getting the participants to submit three speaking portfolios so as to investigate whether or not there is a statistically difference between the ECT, speaking quiz and the three speaking portfolio scores of the experimental and control group.

\section{Results}

\subsection{Results as to the ECT}

Table 1 below illustrates the statistical values obtained by running independent samples t-test in order to analyze participants' scores from the ECT.

Table 1. T-Test results of the speaking exam scores in the ECT

\begin{tabular}{lllllll}
\hline Group & $\mathrm{N}$ & $\mathrm{M}$ & $\mathrm{SD}$ & $\mathrm{t}$ & $\mathrm{df}$ & $\mathrm{P}$ \\
\hline Experimental & 19 & 8,0658 &, 55178 & -1043 & 34 &, 304 \\
Control & 17 & 7,8235 &, 82805 & & &
\end{tabular}

As depicted in Table 1, there is no statistically significant difference between the mean values of the ECT scores of the groups, $\mathrm{p}=, 304>, 005$, indicating that attending more lessons taught by NESTs did not result in getting higher scores on the speaking exam of the ECT.

\subsection{Results as to the speaking quiz}

Another data collection tool used to investigate if being predominantly taught by NESTs leads to a higher achievement level in speaking skill is the speaking quiz. Table 2 below demonstrates whether there is a statistically significant difference between the speaking quiz scores of the experimental and control group.

Table 2. T-test results of the speaking quiz

\begin{tabular}{lllllll}
\hline Group & $\mathrm{N}$ & $\mathrm{M}$ & $\mathrm{SD}$ & $\mathrm{t}$ & $\mathrm{df}$ & $\mathrm{P}$ \\
\hline Experimental & 19 & 7,9737 &, 97857 & $-1,316$ & 34 &, 197 \\
Control & 17 & 7,4412 & 1,42940 & & & \\
\hline
\end{tabular}

As shown in Table 2, no statistically significant difference exists between the speaking quiz scores of the experimental and control group, $\mathrm{p}=, 197>, 005$. In line with the interpretation of the statistical values demonstrated in Table 1, the p-value in Table 2 shows that no statistically significant difference that could spring from receiving English language education mainly from NESTs was observed between the scores of the groups.

\subsection{Results as to the speaking portfolios}

Table 3 below displays descriptive statistics belonging to the speaking portfolios. In an effort to explore whether or not there was a statistically significant difference between the control and experimental group's scores on the three speaking portfolios, independent samples t-test was conducted. 
Table 3. T-test results of the speaking portfolios

\begin{tabular}{lllllll}
\hline PortfolioGroup & & $\overline{\mathrm{x}}$ & $\mathrm{SD}$ & $\mathrm{t}$ & $\mathrm{df}$ & $\mathrm{P}$ \\
\hline Port. 1 & Control & 8,2059 & 1,18663 & $-1,062$ & 34 &, 296 \\
& Experimental & 8,5789 &, 91687 & & & \\
\multirow{3}{*}{ Port. 2 } & Control & 8,2529 &, 76577 & $-1,047$ & 34 &, 304 \\
& Experimental & 8,4474 &, 94126 & & & \\
& & & & & &, 041 \\
Port. 3 & Control & 7,4512 & 1,12147 & $-2,123$ & 34 & \\
& Experimental & 8,5432 & 1,23886 & & & \\
\hline
\end{tabular}

As depicted in Table 3, in the first speaking portfolio, a slight difference exits between the mean values of the experimental and control group, $\bar{x}=8.2059,8.5789$ respectively. There is also no statistically significant difference between the first portfolio scores of the experimental and control group, $\mathrm{p}=, 296>, 005$, which shows that being mostly taught by NESTs did not yield scores that could be interpreted as statistically significant. Additionally, Table 3 demonstrates statistical values belonging to the second speaking portfolio. The mean value for the control group on the second speaking portfolio is 8,2529 , whereas it is slightly higher in the experimental group, $\bar{x}=8,4474$. The $p$ value of the second speaking portfolio is, 304 , indicating no statistically significant difference between the scores of the participants in the experimental and control group. Regarding the third speaking portfolio, Table 3 displays that the difference between the mean values of the experimental and control group increases in that the mean value for the experimental group is 8,5432 whilst it is 7,4512 for the control group. The increased difference in the mean values brings about a statistically significant difference between the experimental and control group as, 041 is smaller than ,005. Considering the mean values belonging to the third speaking portfolio, it could be stated that the experimental group outperformed the control group, resulting in a statistically significant difference between groups and that statistically significant difference appearing in the third speaking portfolio stands in contrast to the results obtained from the first and second speaking portfolios.

\section{Discussion}

The findings obtained in this experimental study showed that participants' achievement levels in speaking skill did not exhibit a statistically significant difference according to the total number of classes taught by NESTs since the participants in the experimental group performed better neither on the exams involving the ECT and the speaking quiz nor on the first and second speaking portfolios. A statistically significant difference was observed only between the groups' scores on the third speaking portfolio. The findings reported in this study appear to be parallel to the results yielded in the study carried out by AlNawrasy (2013) in that there was no statistically significant difference in the speaking test scores of the subjects instructed by NESTs and NNESTs. Similarly, the results reported by Adigüzel and Özdoğru (2017) revealed no statically significant difference between the post-speaking test scores of the participants taught by NESTs and NNESTs.

The literature encapsulates studies (Llurda \& Huguet, 200; Guerra, 2017; Reves \& Medgyes, 1994; Samimy \& Brutt-Giffler, 1999) the findings of which reveal the acknowledgement of the differences between NESTs and NNESTs either by students or NNESTs themselves. The findings in those papers bring the distinctions in language proficiency, particularly proficiency in speaking skill, between NESTs and NNESTs into the forefront. NESTs' language proficiency is unequivocally better than NNESTs, yet 
the question that goes over one's head is whether this difference causes compelling quality differences in teaching practices. Research studies exploring student perceptions concerning the teaching practices of NESTs and NNESTs (Berke \& Medgyes, 2006; Diaz, 2015; Guerra, 2009; Lasagabaster \& Sierra, 2006; Lewis, Sonsaat \& Link, 2017) reveal that students prefer NESTs over NNESTs when it comes to teaching speaking and pronunciation. Students' perceptions regarding having the opportunity to develop their speaking skills more as a consequence of learning English from NESTs might not come true as could be seen in the findings of this study. That is to say, having NESTs need not culminate in better achievement levels in speaking skill. The point worth emphasizing at this point is the more value having been given thus far to NESTs by students because they may not be informed about the results of the studies revealing that being taught by NESTs does not lead to more improvement in speaking skill in comparison to learning English from NNESTs. Nothing may change in the eyes of the students about perceiving NESTs better at teaching speaking and pronunciation even if they learn about the findings of the studies. Nevertheless, this possibility need not prevent the initiatives to be taken to inform students about the research revealing the opposite of their expectation, and because NNESTs have less chance of being employed when they apply for a job for which NESTs are also applicants.

People in charge of the administration of language schools hire NESTs and advertise their schools by highlighting the point that it would be easier for students to improve their speaking skills by virtue of learning English from NESTs. This might bring about the fear of not being able to find a job on the part of NNESTs in EFL/ESL contexts, as NESTs are valued more in contrast to NNESTs. In the study done by Gonzales (2016), it is revealed that NNESTs are afraid of their prospective professional lives. Nonetheless, now that development in speaking skills may be achieved with ease on the condition that the teacher is a NEST, achievement levels in speaking skill of the students who are instructed by NESTs need to be higher than the ones the students taught by NNESTs have, which contradicts with the findings of this study and the ones presented in the research conducted by Al-Nawrasy (2013) and Adigüzel and Özdoğru (2017).

\section{Conclusions}

The findings reported in this study will fill the gap in the literature in relation to the scarcity of the studies examining the correlation between learning English from NESTs and achieving more improvement in speaking skill. The results showed that a statistically significant difference in the speaking scores of the experimental and control group resulting from being taught by NESTs and NNESTs was not observed. Nonetheless, this does not mean that this paper has no limitations. One of the limitations is that an interview was not carried out with the participants at the end of the study. Further studies could investigate the perceptions of the students concerning the influence of being taught by NESTs after informing them about the results obtained from the analysis of the speaking scores of the groups taught predominantly or totally by NESTs and NNESTs. By doing so, the changes, if any, in students' perceptions as to better improvement in speaking skill enabled by being instructed by NESTs can be investigated. Furthermore, research on the impact of the nationality of English language teachers on students' speaking skills needs to be extended considering the limited number of studies on this topic, because the prejudice as with the mainstream conception "English is taught better by NESTs" may be eliminated through carrying out more studies and sharing their results with not only the academics but also students and employers. 


\section{References}

Adıgüzel, O. C., \& Özdoğru, F. (2017). Effects of Turkish and English speaking teachers on students' foreign language skills. Kastamonu Education Journal, 25(1). 172-186.

Benke, E., \& Medgyes, P. (2006). Differences in teaching behaviour between native and non-native speaker teachers: As seen by the learners. E. Llurda (Ed.) Non-native language teachers, challenges and contributions to the profession (pp. 195-215). New York: Springer.

Boonkit, K. (2010). Enhancing the development of speaking skill for non-native speakers of English. Procedia Social and Behavioral Sciences, 2(2), 1305-1309.

Bygate, M. (2010). Speaking. Oxford: Oxford University Press.

Cepik, S., \& Yastıbaş, A. E. (2013). The use of e-portfolio to improve English speaking skill of Turkish EFL learners. The Anthropologist, 1(2), 307-317.

Díaz, N. R. (2015). Students' preferences regarding native and non-native teachers of English at a university in the French Brittany. Procedia-Social and Behavioral Sciences, 173, 93-97.

Dowling, F. (1957). Teaching impromptu speaking. The Speech Teacher, 6(3), 205-208.

Ebadi, S., \& Asakereh, A. (2017). Developing EFL learners' speaking skills through dynamic assessment: A case of a beginner and an advanced learner. Cogent Education, 4(1), 1-18.

Feuer, M. J., Towne, L., \& Shavelson, R. J. (2002). Scientific culture and educational research. Educational Researcher, 31(8), 4-14.

Forbes, K., \& Fisher, L. (2018). The impact of expanding advanced level secondary school students' awareness and use of metacognitive learning strategies on confidence and proficiency in foreign language speaking skills. The Language Learning Journal, 46(2), 173-185.

Gan, Z. (2013). Understanding English speaking difficulties: An investigation of two Chinese populations. Journal of Multilingual and Multicultural Development, 34(3), 231-248.

Gonzales, J. J. V. (2016). Self-perceived non-nativeness in prospective English teachers' self-images. RBLA, 16(3), 461-491.

Gonzales, E. R., \& Castaneda, M. E. (2018). The effects and perceptions of trained peer feedback in L2 speaking: Impact on revision and speaking quality. Innovation in Language Learning Teaching, 12(2), 120-136.

Guerra, L. (2009). Teaching and Learning English as an International Language in Portugal. Policy, Practice and Perceptions. Saarbrücken: VDM Verlag.

Guerra, L. (2017). Students' perceptions and expectations of native and non-native speaking teachers. J. D. D. M. , Agudo (Ed.). Native and non-native teachers in English language classrooms (pp. 183205). Boston: Walter de Gruyter Inc.

Gupta, W., \& Stern, C. (2015). Comparative effectiveness of speaking vs. listening in improving spoken language of disadvantaged young children. The Journal of Experimental Education, 38(1), 54-57.

Hassani, K., Nahvi, A., \& Ahmadi, A. (2013). Design and implementation of an intelligent virtual environment for improving speaking and listening skills. Interactive Learning Environments, 24(1), 252-271.

Hayward, P. A. (2017). Incorporating TED Talk assignments into a public-speaking course. Communication Journal, 31(4), 239-244. 
Hudges, R. (2011). Teaching and researching speaking. Edinburgh: Pearson Education Limited.

Hunter, K. M., Westwick, J. N., \& Haleta, L. L. (2014). Assessing success: The impacts of a fundamentals of speech course on decreasing public speaking anxiety. Communication Education, 63(2), 124-135.

Lasagabaster, D., \& Sierra, J. M. What do students think about the pros and cons of having a native speaker. E. Llurda (Ed.) Non-native language teachers, challenges and contributions to the profession (pp. 217-241). New York: Springer.

Lewis, J., Sonsaat, S., Link, S., \& Barriuso, T. A. (2016). Native and nonnative teachers of L2 pronunciation: Effects on learner performance. TESOL Quarterly, 50(4), 894-931.

Medgyes, P. (1992). Native or non-native: who's worth more? English Language Teaching Journal, 46 (4), 340-49.

Lewis, J., Sonsaat, S., \& Link, S. (2017). Students' beliefs about native and non-native pronunciation teachers. J. D. D. M. , Agudo (Ed.). Native and non-native teachers in English language classrooms (pp. 183-205). Boston: Walter de Gruyter Inc 205-237.

Llurda, E., \& Huguet, A. (2003). Self-awareness in NNS EFL primary and secondary school teachers. Language Awareness, 12(3\&4), 220-233.

Mahfouz, S. M., Ihmeideh, F. M., (2009). Attitudes of Jordanian university students towards using online chat discourse with native speakers of English for improving their language proficiency. Computer Assisted Language Learning, 22(3), 207-227.

Nation, I. S. P., \& Newton, J. (2009). Teaching ESL/EFL Listening and Speaking. New York: Routledge.

Reves, T., \& Medgyes, P. (1994). The non-native English speaking EFL/ESL teachers' self-image: An international survey. System, 22(3), 353-367.

Richards, J. C. (2008). Teaching listening and speaking: From theory to practice. Cambridge: Cambridge University Press.

Samimy, R., \& Brutt-Griffler, J. (1999). To be a native or nonnative speaker: Perceptions of "nonnative" students in a graduate TESOL program. In G. Braine (Ed.), Nonnative educators in English language teaching (pp. 127-144). Mahwah, NJ: Lawrence Erlbaum.

Sun, Z., Lin, C. H., You, J., Shen, H. J. Qi, S., \& Luo, L. (2017). Improving the English speaking skills of young learners through mobile social networking. Computer Assisted Language Learning, 3(4), 304-324.

Uchihara, T., \& Saito, K. (2016). Exploring the relationship between productive vocabulary knowledge and second language oral ability. The language learning Journal, 47(1), 64-75.

Uztosun, M. S., Skinner, N., \& Cadorath, J. (2014). An action research study designed to implement student negotiation to improve speaking classroom practice in Turkey. Educational Action Research, 22(4), 488-504.

Zou, B. (2013). Teachers' support in using computers for developing students' listening and speaking skills in pre-sessional English courses. Computer Assisted Language Learning, 26(1), 83-99. 


\section{Ana dili İngilizce olan öğretmenlerden İngilizce öğrenmek konuşma becerisindeki ilerlemeyi daha fazla arttırır mı?}

$\ddot{O} z$

Ana dili İngilizce olan öğretmenlerden İngilizce öğrenmenin konuşma becerisindeki yeterlikte daha fazla ilerleme sağladığı düşünülmektedir. Bu çalışma, ana dli İngilizce olan öğretmenlerden İngilizce öğrenmenin, İngilizceyi yabanc1 dil olarak öğrenen yetişkin öğrencilerin konuşma becerisinde daha fazla ilerlemeyle sonuçlanıp sonuçlanmadığını araştırmak için yürütülmüştür. Denek grubundaki katılımcılarla kontrol grubundaki katılımcıların konuşma puanları arasında istatistiksel olarak anlamlı bir fark olup olmadığını irdelemek amacıyla deneysel araştırma tasarımı kullanılmıştır. Denek grubu, ana dili İngilizce olmayan öğretmenlerden daha fazla ders alan kontrol grubuna kıyasla, ana dili İngilizce olan öğretmenlerden daha fazla ders almışlardır. Çalışmanın süresi olan sekiz hafta boyunca katılımcılar üç konuşma portfolyosu teslim etmiş, bir kısa konuşma sınavı ve bir de modül sonu sınavına girmişlerdir. Katılımcıların kısa konuşma sınavı, modül sonu sınavı ve konuşma portfolyolarından aldıkları puanlar bağımsız örneklem t-testi ile analiz edilmiştir. Elde edilen bulgular, kontrol ve denek grubunun ne modül sonu sınavından ne küçük konuşma sınavından ne de birinci ve üçüncü konuşma portfolyolarından aldıkları puanlar arasında anlamlı bir farklılık olmadığını ortaya koymaktayken, grupların üçüncü konuşma portfolyosundan aldıkları puanlar arasında anlamlı bir farklılık olduğunu göstermektedir. Sonuçlar, ana dili İngilizce olan öğretmenlerle İngilizce konuşma daha iyi öğrenilebilir kanısına yönelik şüphe uyandırabilir.

Anahtar sözcükler: İngilizceyi yabancı dil olarak öğrenen yetişkin öğrenciler; ana dili İngilizce olan öğretmeler; ana dili İngilizce olmayan öğretmenler; konuşma becerisi; konuşma becerisinde ilerleme

\section{AUTHOR BIODATA}

Gülten KOŞAR is working as an Assist. Prof. Dr. in the department of English Language Teaching at Hatay Mustafa Kemal University. She received her BA in English Language and Literature from Hacettepe University, $\mathrm{MA}$ and $\mathrm{PhD}$ in English Language Teaching from Çukurova University. Her research concentrations include second/foreign language learning, teaching language skills, foreign language teacher education, and last but not least teaching English to adult and young learners. 